\title{
Management of Lambdoid Craniosynostosis: A Comprehensive and Systematic Review
}

\author{
Taylor Reardon $^{\text {a }}$ Brian Fiani $^{b}$ Jacob Kosarchuk ${ }^{c}$ Anthony Parisid \\ Nathan A. Shlobin ${ }^{e}$ \\ ${ }^{a}$ Kentucky College of Osteopathic Medicine, Pikeville, KY, USA; ${ }^{b}$ Desert Regional Medical Center, Palm Springs, CA,

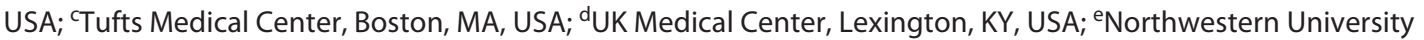 \\ Feinberg School of Medicine, Chicago, IL, USA
}

\section{Keywords \\ Lambdoid craniosynostosis · Neurosurgery · Craniofacial · \\ Pediatrics · Plastic surgery}

\begin{abstract}
Background: Craniosynostosis is a condition characterized by the premature fusion of 2 or more skull bones. Craniosynostosis of the lambdoid suture is one of the rarest forms, accounting for $1-4 \%$ of all craniosynostoses. Documented cases are separated into simple (single suture), complex (bilateral), and associated with adjacent synostoses ("Mercedes Benz" Pattern) or syndromes (i.e., Crouzon, Sathre-Chotzen, Antley-Bixler). This condition can manifest phenotypic deformities and neurological sequelae that can lead to impaired cognitive function if improperly treated or left undiagnosed. Preferred surgical techniques have varied over time but all maintain the common goals of establishing proper head shape and preventing of complications that could contribute to aforementioned sequelae. Summary: This comprehensive review highlights demographic distributions, embryological development, pathogenesis, clinical presentation, neurological sequelae, radiologic findings, surgical techniques, surgical outcomes, and postoperative
\end{abstract} presentation. In addition, a systematic review was conducted to explore the operative management of lambdoid craniosynostosis using PubMed, Embase, and Scopus databases, with 38 articles included after screening. Key Messages: Due to a low volume of published cases, diagnosis and treatment can vary. Large overlap in presentation can occur in patients that display lambdoid craniosynostosis and posterior plagiocephaly, furthering the need for comprehensive analysis. Possessing the knowledge and tools to properly assess patients with lambdoid craniosynostosis will allow for more precise care and improved outcomes.

(c) 2021 S. Karger AG, Basel

\section{Introduction}

The earliest documented case of isolated lambdoid craniosynostosis was a left lambdoid synostosis in an immature human fossil dated at a minimal age of 530,000 years [1]. Currently, the prevalence of true lambdoid craniosynostosis remains low, contributing to $1-4 \%$ of all craniosynostoses [2]. The exact etiology of the condition is not known; however, a genetic predisposition is suggestive, as there have been documented cases of familial [3]

Correspondence to:

Taylor Reardon, taylorreardon@upike.edu 
Table 1. Delineated search terms used in the systematic review

\begin{tabular}{|c|c|}
\hline Database & Search terms \\
\hline PubMed & $\begin{array}{l}\{(\text { "craniosynostoses"[MeSH] AND "lambdoid*") OR "lambdoid craniosynostos*" OR "lambdoid synostos*" OR "lambdoidal } \\
\text { craniosynostos*" OR "lambdoidal synostos*" OR ("lambdoid*" AND ["craniosynostos*" OR "synostos*"])\} }\end{array}$ \\
\hline Scopus & $\begin{array}{l}\text { \{"Lambdoid craniosynostos*" OR "lambdoid synostos*" OR "lambdoidal craniosynostos*" OR "lambdoidal synostos*" OR } \\
\text { ("lambdoid*" AND ["craniosynostos*" OR "synostos*"])\}:ti,ab,kw }\end{array}$ \\
\hline
\end{tabular}

and dizygotic twins [4] lambdoid craniosynostoses. A clinical presentation of true lambdoid craniosynostosis is highly variable given a large degree of overlap with deformational posterior plagiocephaly, complicating diagnosis. Common physical examination findings include frontal bossing, posterior plagiocephaly, and changes in ear position, torticollis, and trapezoidal head shape [5]. Because of the variability in presentation, confirmation of diagnosis is obtained with computed tomography (CT) scan and can guide the surgeon toward the proper surgical intervention. Initially, open-strip craniectomy was the common treatment method; however, complications from the procedure and development of new techniques have promoted open cranial vault reconstruction and endoscopic suturectomy to the gold standard for surgical management. Postoperative considerations for patients with lambdoid craniosynostosis include monitoring of intracranial pressure (ICP), lab value maintenance, and implementation of helmet-molding orthoses to prevent suture refusion. A thorough evaluation and attention to detail at every step is necessary for a favorable outcome in a patient with lambdoid craniosynostosis.

\section{Methods}

A systematic review regarding the management of isolated lambdoid craniosynostosis was performed in accordance with the Preferred Reporting Items for Systematic Reviews and Meta-Analysis (PRISMA) 2020 guidelines [6]. No protocol was registered. PubMed MEDLINE (National Library of Medicine), Embase (Elsevier), and Scopus (Elsevier) were searched on June 18, 2021, using keywords including lambdoid craniosynostosis with no restrictions on language, date, or article type (Table 1). Figure $1 \mathrm{dem}-$ onstrates a PRISMA flowchart summarizing article inclusion (Fig. 1).

After the search was completed, duplicates were removed utilizing the automated deduplication function in Endnote (Clarivate
Analytics, London, UK). All remaining articles were screened by title and abstract for relevance. Articles progressing to full-text review were screened based on prespecified inclusion and exclusion criteria. Inclusion criteria were published in or translated into the English language, with full-text available, providing primary data, population of patients with isolated unilateral or bilateral lambdoid craniosynostosis, and discussing management and associated patient outcomes. Exclusion criteria were conference abstracts, commentaries, letters to the editor, reviews, meta-analyses, other subtypes of craniosynostosis, and lack of outcomes of management. Studies discussing multiple subtypes of craniosynostosis were included if outcomes specific to isolated lambdoid craniosynostosis patients were provided. A second reviewer replicated the search strategy and screening. Disagreements were reconciled by consensus.

After the set of included articles was finalized, studies were reviewed for characteristics designated a priori such as bibliographic data, aim, design, study participants, operative and postoperative details, outcomes, and length of follow-up. Outcomes of interest were blood loss, blood transfusion, major complications, reoperation, and head contour. The World Bank income classification was used to designate the income status countries of origin for all included studies [7]. The quality of each study was evaluating using the GRADE framework [8]. The risk of bias for each included study was determined using the ROBINS-I tool [9]. A judgment on the overall risk of bias was leveled by considering the risk of bias of all included studies in aggregate.

\section{Results}

A search of the literature resulted in 38 articles published from 1984 to 2021 that met eligibility criteria [5, $10-46]$. Out of the 38 total articles, 32 (84.2\%) were case series, $5(13.2 \%)$ were retrospective cohort analyses, and $1(2.6 \%)$ was a case report. In total, 433 patients were reported to have received surgical intervention for either unilateral or bilateral lambdoid craniosynostosis, with 1 article not reporting these data [37]. In the studies that included separate data for both isolated and bilateral syn- 
Fig. 1. PRISMA flowchart outlining inclusion and exclusion criteria for systematic review.

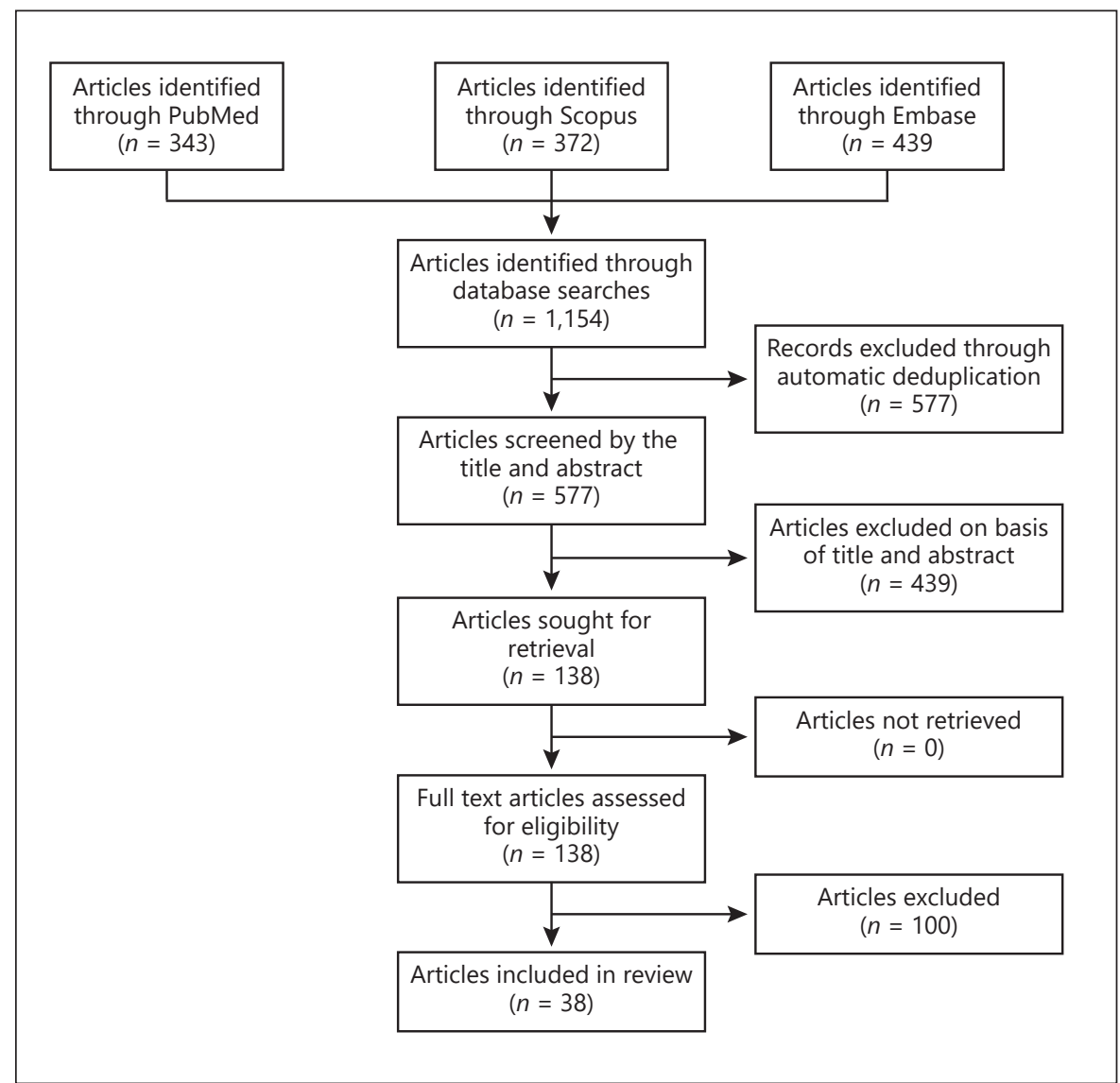

ostoses, $268(88.4 \%)$ isolated and $35(11.6 \%)$ bilateral lambdoid craniosynostoses were recorded.

The most common surgical intervention utilized was strip craniectomy, with other cited articles utilizing "Sand Dollar and Staves" technique, posterior vault remodeling, sunrise technique, and distraction osteogenesis. The mean blood loss ranged from 7.5 to $640.5 \mathrm{~mL}$ and mean postoperative blood transfusions ranged from 0 to 117 $\mathrm{mL}$. Head contour results showed improvement in entire cohort for 18 (69.2\%) articles with 8 (31.8\%) mentioning no change in parameters such as cranial fossa size, residual occipital deformities, hemifacial deficiencies, posterior fossa deflection, petrous ridge asymmetry, and anteroinferior ipsilateral ear displacement. The rate of complication ranged from $0 \%$ to $20 \%$ but never exceeded 1 patient per cohort. The rate of reoperation ranged from $0 \%$ to $23.8 \%$, with a maximum of 5 patients requiring reoperation in 1 cohort. The average length of hospitalization ranged between 1 and $<5$ days. The mean length of follow-up ranged from 7 months to 84 months with $50 \%$ $(19 / 38)$ of articles documenting these data. The quality of

Management of Lambdoid Craniosynostosis evidence was low in most studies. Given that most included studies had a high risk of bias, the risk of bias in this systematic review was high overall (Table 2).

\section{Discussion}

\section{Etiology and Pathogenesis}

Craniosynostosis as a disease entity is fairly common, affecting 1 in 2,100-2,500 births [47-49]. Approximately $85 \%$ of children with craniosynostosis are asymptomatic (e.g., have isolated craniosynostosis), $7 \%$ are symptomatic, and $9 \%$ show symptoms of syndromic disease [50, 51]. Lambdoid craniosynostosis is the rarest variant, accounting for approximately $2 \%$ of all craniosynostosis cases and affecting 1 in 33,000 infants [5, 52-54]. According to a recent large case series, there appears to be no predilection for gender ( $52 \%$ male, $48 \%$ female) or laterality (52\% left sided, $48 \%$ right sided).

In the developing embryo, the cranial vault forms from the mesenchymal tissue that is initially arranged as a cap- 


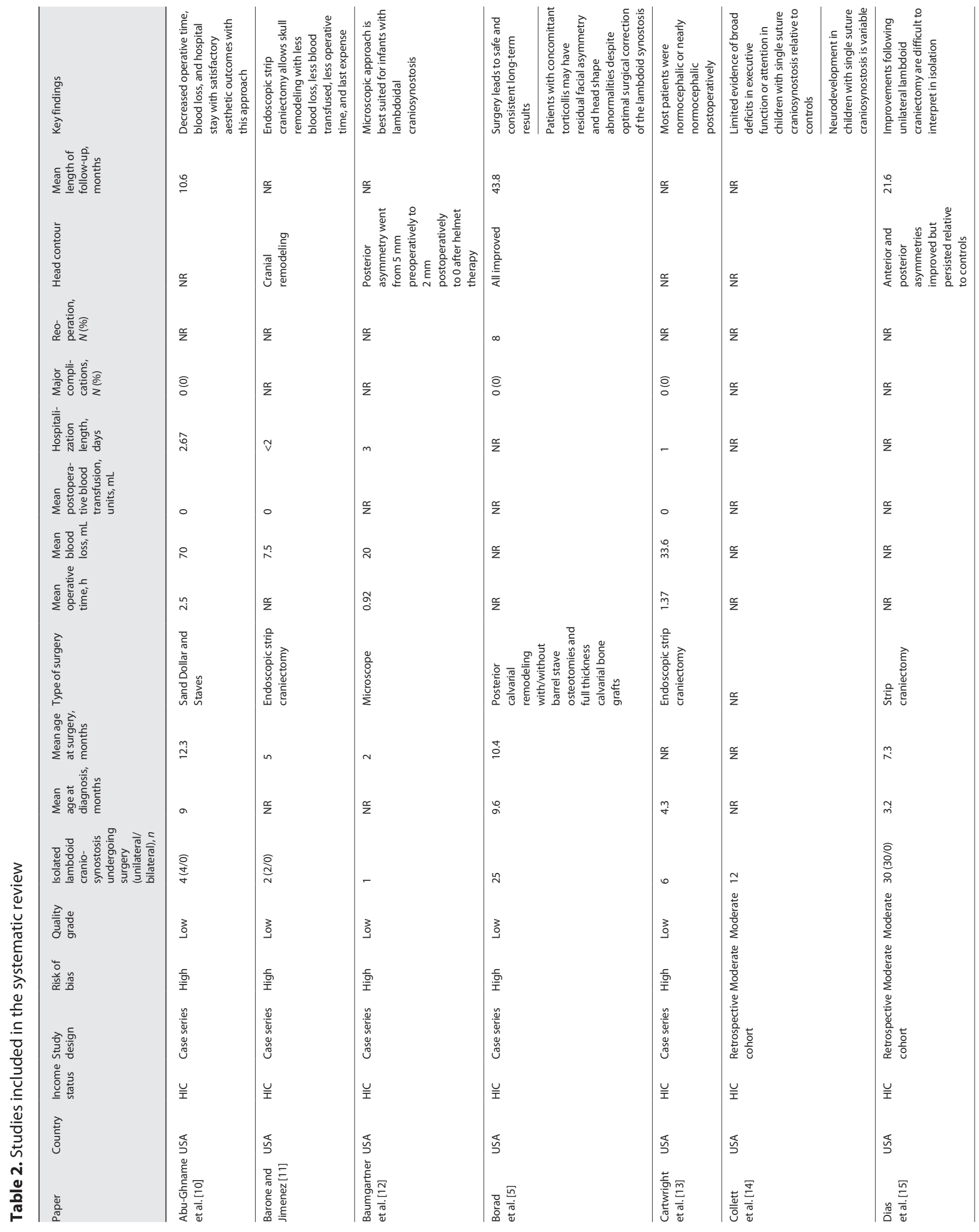




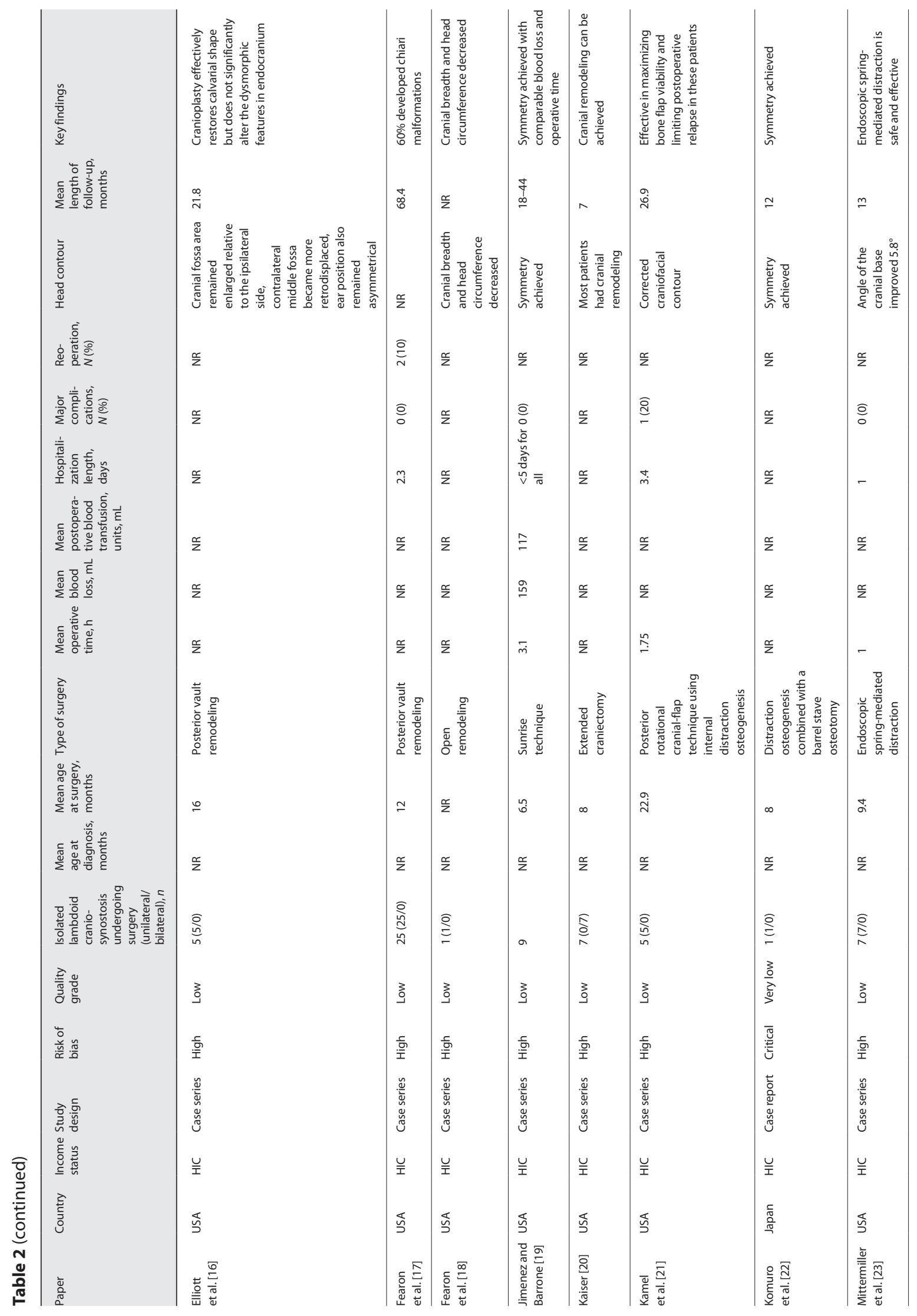




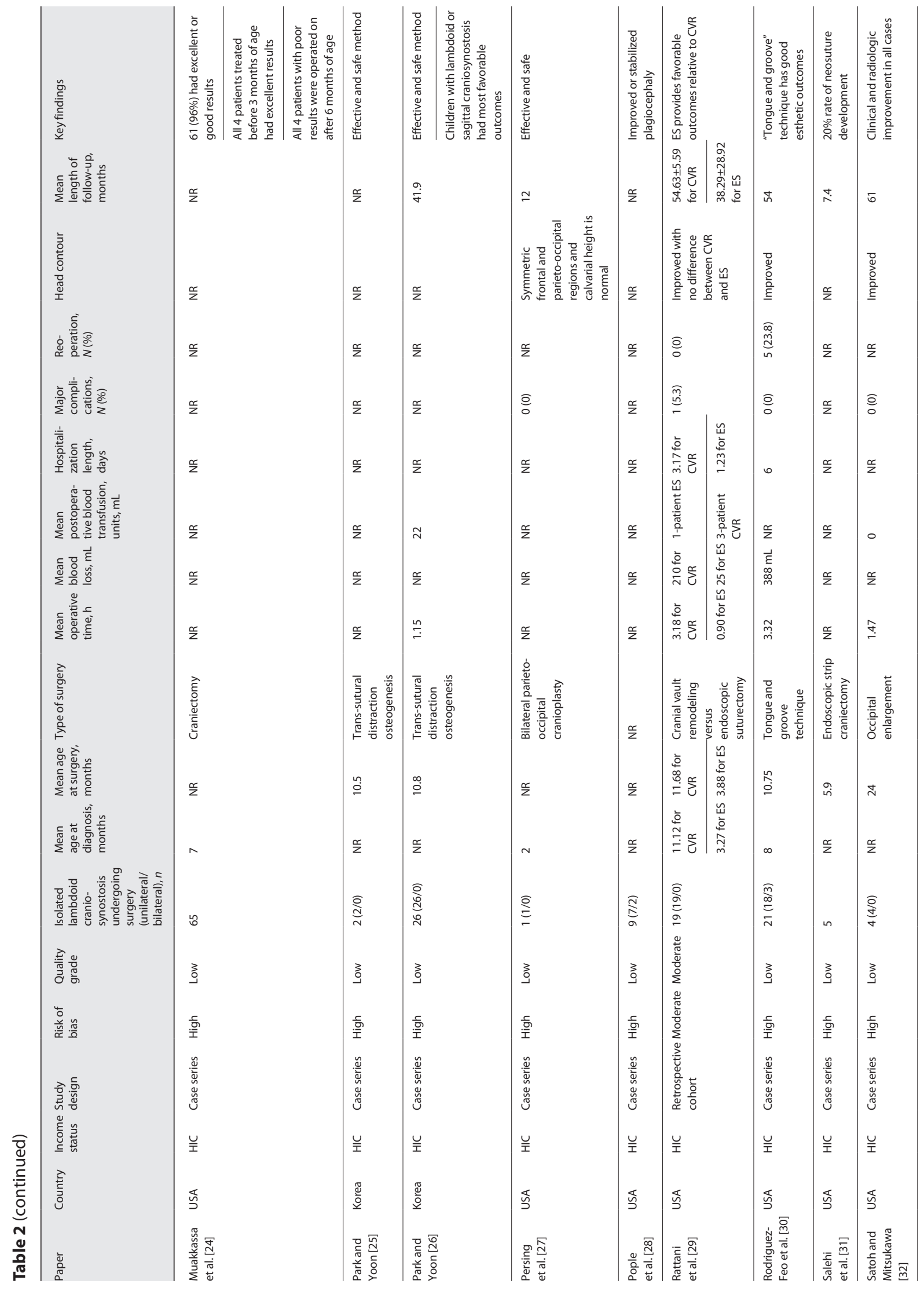




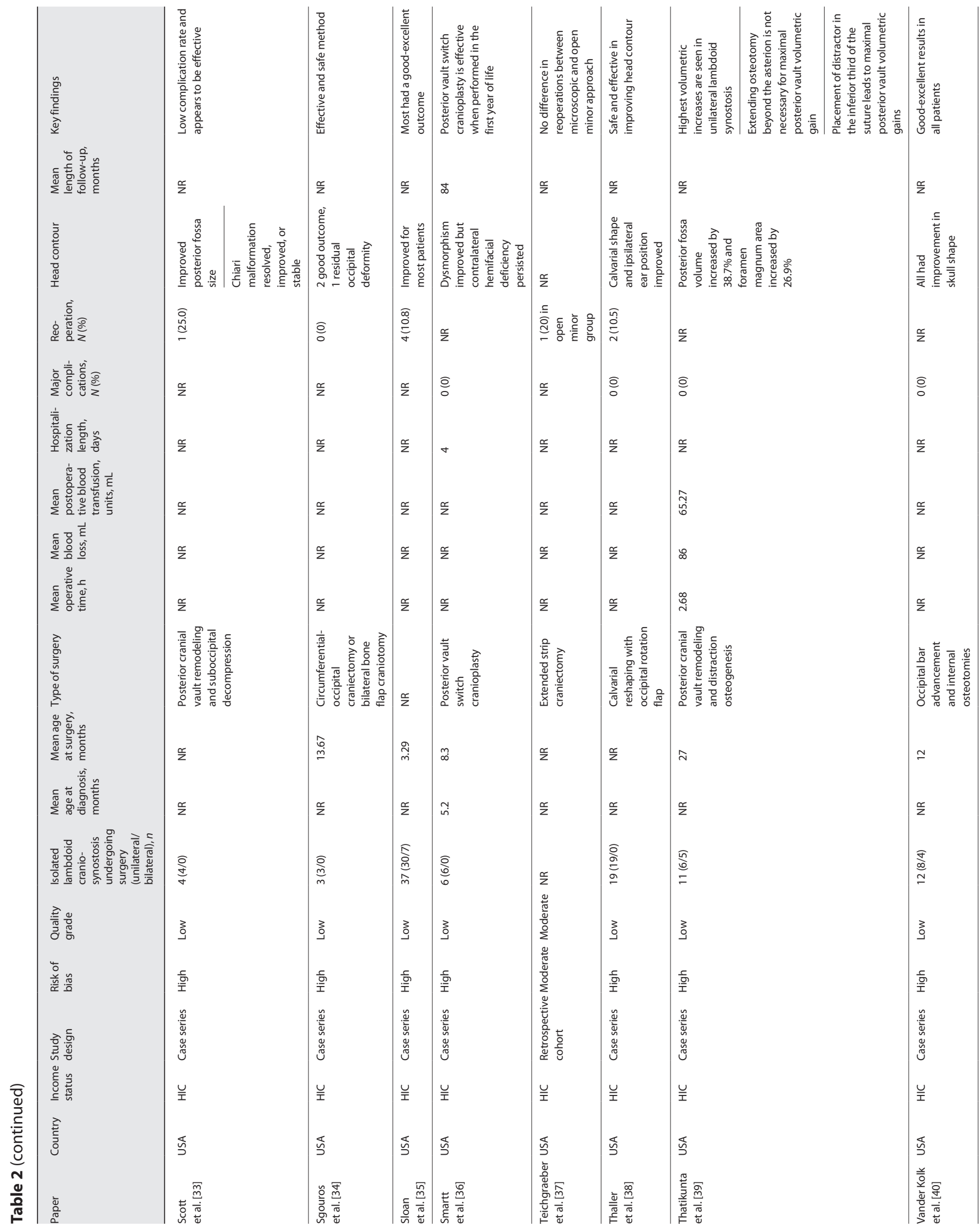




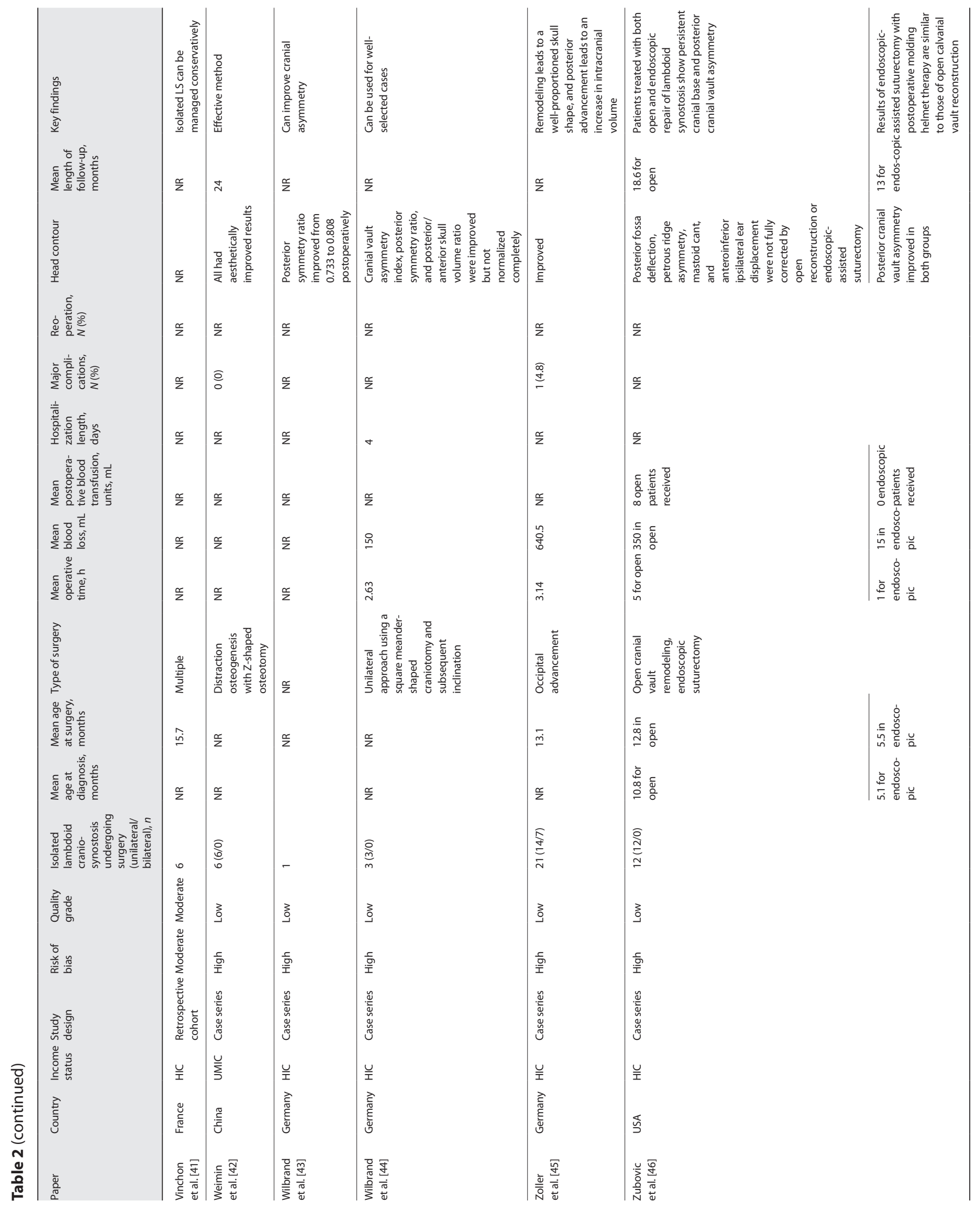


Table 3. Categorical display of genetic mutations, inheritance patterns, and phenotypic features associated with syndromes that display lambdoid craniosynostosis

\begin{tabular}{llll}
\hline Syndrome & Mutation & Inheritance & Other features \\
\hline Crouzon & FGFR2, FGFR3 & $\begin{array}{l}\text { Autosomal } \\
\text { dominant }\end{array}$ & $\begin{array}{l}\text { Midface hypoplasia, exophthalmos, cervical vertebral fusion, hearing loss, } \\
\text { hydrocephalus }\end{array}$ \\
\hline Sathre-Chotzen & TWIST1, FGFR2 & $\begin{array}{l}\text { Autosomal } \\
\text { dominant }\end{array}$ & Parietal foramina, syndactyly, heart defects, hydrocephalus \\
\hline Antley-Bixler & FGFR2 & $\begin{array}{l}\text { Autosomal } \\
\text { recessive }\end{array}$ & $\begin{array}{l}\text { Midface hypoplasia, choanal atresia, joint contractures, radiohumeral synostosis, } \\
\text { hydrocephalus, dysmorphic facies, renal malformations, gynecologic malformations, } \\
\text { syndactyly, arachnodactyly }\end{array}$ \\
\hline
\end{tabular}

FGF, fibroblast growth factor.

sular membrane around the developing brain [54-56]. The outer mesenchymal layer is then formed by intramembranous ossification, which is dependent on the direction of forces applied by the developing brain. The developing brain is also surrounded by dural fibers, which are attached to sutures at sites of approximation of membranous bones and become sites of bony expansion [5763]. This process is controlled by deposition of osteoid, bone remodeling, and displacement by the expanding brain, and sutural fusion is regulated by the underlying dura. Though the pathogenesis of craniosynostosis is believed to be multifactorial, there are a handful of mutations in molecular pathways and transcription factors that are implicated in disease development [63-68]. The most ubiquitous is fibroblast growth factor (FGF) $[53,60$, 63,69 ]. A gain-of-function mutation is implicated in several syndromic causes of craniosynostosis including Crouzon, Saethre-Chotzen, and Antler-Bixley syndromes (Table 3) [53, 69-73]. The FGF receptor is a tyrosine kinase and, among other functions, regulates osteoblast differentiation and maturation. Transforming growth factor beta has also been shown to be involved in craniosynostosis $[74,75]$. The transcription factor TWIST is a regulator of FGFR1, FGFR2, FGFR3, and the osteogenic transcription factor Runx2 and has been associated with the Saethre-Chotzen syndrome [53, 64, 72, 76-78]. The transcription factor MSX2 has also been shown to cause skull ossification defects in a loss of function mutation $[79,80]$. In addition to these molecules, there are also aberrant mechanical signals from the developing brain and mesenchymal cells that migrate to sutures that are involved in the development of craniosynostosis. Additionally, there are numerous environmental factors that are implicated in the development of craniosynostosis, including intra- uterine head restraint, abnormal fetal positioning, oligohydramnios, teratogen (such as tobacco and valproate) exposure, prematurity, macrosomia, nulliparity, plurality, low birth weight, and shunted hydrocephalus $[49,81-$ 85]. These causes are believed to account for $80 \%$ of all cases. Genetic mutations are often single mutations. Chromosomal abnormalities and syndromic conditions lend to the classification of syndromic and nonsyndromic types of craniosynostosis [53, 60, 86, 87]. Most syndromes are autosomal dominant, but up to $50 \%$ of cases arise de novo $[69,88]$. Incomplete penetrance and variable expressivity complicate this picture [72, 89]. There have also been a small handful of reported cases where isolated lambdoid craniosynostosis was passed from father to son [3]. In the developing embryo, Virchow's law provides a basis for the occurrence of craniosynostosis: premature fusion leads to excessive growth perpendicular to patent suture along the path of least resistance [90-92].

\section{Diagnosis}

Craniosynostosis is a clinical diagnosis that is usually made in the first year of life [91]. The diagnosis begins with thorough prenatal and family histories. Careful attention must be paid to the child's progress with developmental milestones. Though in the normal adult the lambdoid suture usually fuses around 26 years of age, in children with craniosynostosis the average age is around 9.6 months [5]. Craniosynostosis can be divided into syndromic versus nonsyndromic, simple (single suture) versus complex (multiple suture), and primary (disorders of intramembranous ossification) and secondary (defective ossification related to hematologic or metabolic disorders, microcephaly from failed brain growth, shunt placement in children with hydrocephalus) subtypes [58]. In- 


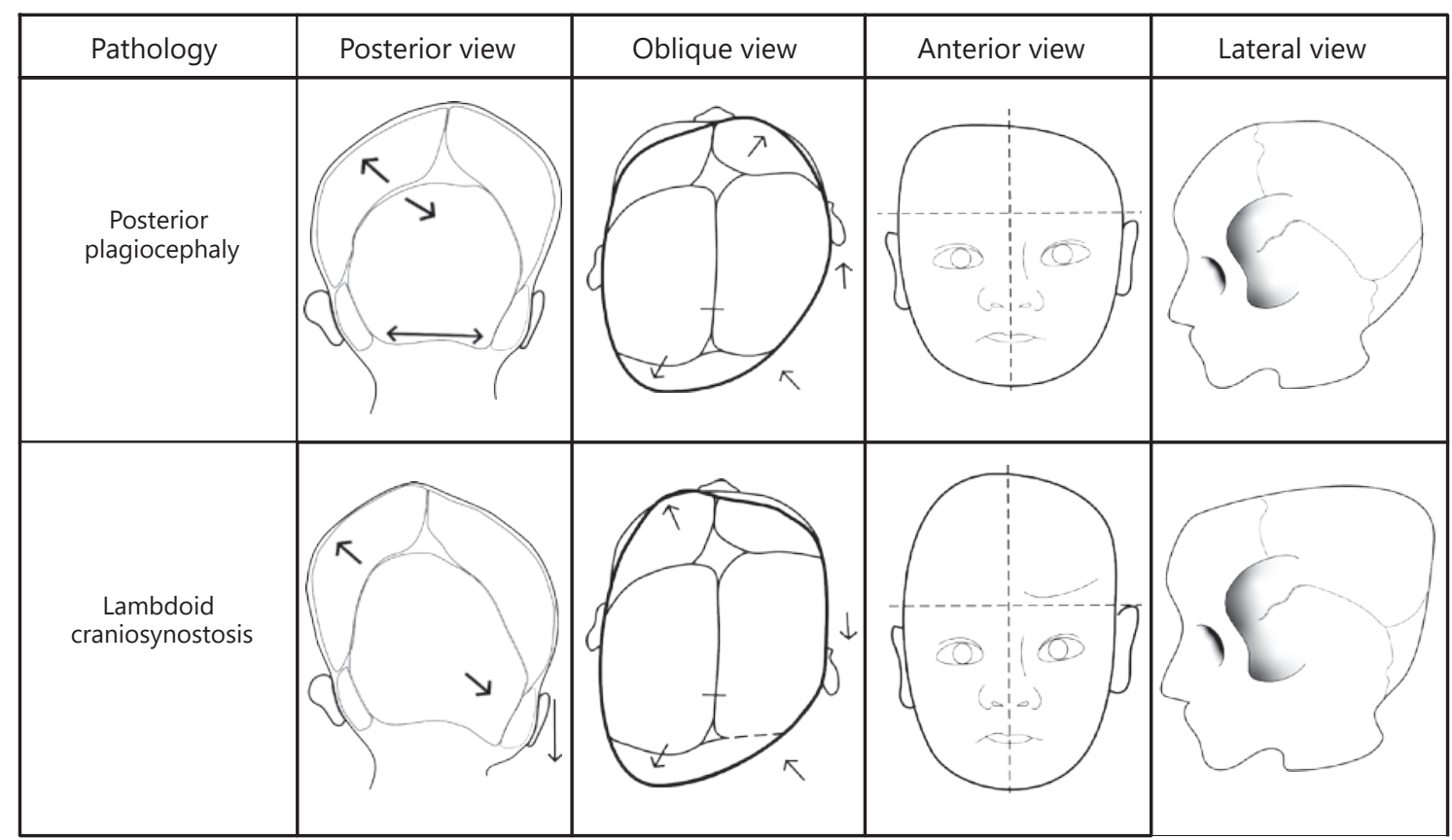

Fig. 2. Similarities and differences between posterior plagiocephaly and lambdoid craniosynostosis from posterior, oblique, anterior, and lateral views (Courtesy of Roger Avila).

terestingly, the premature fusion of the asterion or mendosal sutures can cause a lambdoid craniosynostosis phenotype with open lambdoid sutures - an important caveat for clinicians to keep in mind [53, 93, 94].

Diagnosis based on the physical exam can be challenging, as lambdoid craniosynostosis can be difficult to differentiate from positional plagiocephaly $[92,95]$. The visual similarities and differences of these 2 conditions are displayed in Figure 2. Children with lambdoid craniosynostosis have trapezoid-shaped skulls, sutural ridging, changes in ear position, downward tilt of the skull base to the ipsilateral side, prominence of the ipsilateral mastoid process which draws the ear inferiorly, and compensatory bossing of the contralateral parietal bone $[96,97]$. Classically, posterior movement of the ear was said to distinguish lambdoid craniosynostosis, but recent studies have demonstrated that the inferior movement of the ear is a more accurate predictor [24]. Of note, these findings can be variable from patient to patient, making accurate diagnosis all the more challenging. Other features can include hyper- or hypotelorism, hypoplasia of the mid-face, abnormal size and shape of the ears, prominent scalp blood vessels, altered fontanel morphology, and signs of intracranial hypertension such as papilledema or sundowning $[88,93,97]$. Children with syndromic cranio- synostosis (SC) also display features such as syndactyly, hearing loss, and other deficits $[98,99]$.

The sequelae of lambdoid craniosynostosis, aside from other syndromic abnormalities, are primarily related to elevated ICP [54, 58, 88, 96, 100-104]. Sensory, respiratory, and neurological function may result, and up to $37 \%$ of children with lambdoid craniosynostosis may have intellectual disability. It is thought that learning disabilities, especially in children with SC, result from restricted brain growth, hydrocephalus, prematurity, and secondary deformations caused by high ICP and large sutures [105].

\section{Imaging}

Proper selection of imaging modalities is necessary to properly categorize and confirm diagnosis of lambdoid craniosynostosis, rule out similar conditions, and guide the surgeon toward the appropriate surgical intervention. While other craniosynostoses, such as multisuture non-SC and SCs, can be largely diagnosed from physical exam and neurological sequelae, lambdoid craniosynostosis is rarer and suture patency is more difficult to observe [106]. CT is the gold standard for imaging and confirmation of true synostoses due to its accuracy and ability to further evaluate structural abnormalities [91]. Other imaging modalities, such as magnetic resonance imaging (MRI), ultrasound, 
and plain radiography, can be used but show less precision in the suture structure. Radiographic presentation can display unilateral or bilateral fusion of the lambdoid sutures, with bilateral fusion present in only $15 \%$ of cases of lambdoid craniosynostosis [107]. Unilateral lambdoid synostosis displays a bony prominence along the sutural line, ipsilateral occipitoparietal flattening, and contralateral occipitoparietal and frontal bossing [66]. Bilateral lambdoid craniosynostosis displays bilateral occipitoparietal flattening, underdevelopment of the posterior fossa, and turricephalic deformities [106, 108]. An even rarer presentation, known as "Mercedes Benz" Pattern craniosynostosis, shows an additional sagittal suture fusion in addition to bilateral lambdoid craniosynostosis [109]. Chiari malformations are also commonly seen in patients with bilateral lambdoid craniosynostosis, mainly due to overcrowding of the posterior cranial fossa [110]. The goal of postoperative imaging is to evaluate the maintenance of head shape and monitor any appearance of new symptoms. Postoperative longitudinal imaging studies are not indicated and have been replaced by nonradiological exams such as 3D laser, morphometric assessment, and smartphone-based photogrammetry [106]. Thorough radiographic analysis of patients with lambdoid craniosynostosis is necessary for optimal outcomes and management.

\section{Surgical Management}

The surgical treatment of craniosynostosis has evolved significantly over time. The unique challenges of caring for patients at such a young age, which carries a higher risk profile, have led to multiple evolutions in treatment for this condition. Initially, open strip craniectomy was the treatment of choice. While patients initially fared well, sutures would often reclose leading to unsatisfactory cosmetic results and recurrence of symptoms in more severe cases. The improvement in operative technique, technology available within the operating room, and improvements in anesthesia administration dovetailed closely with the emergence of craniofacial surgery as a discipline unto itself. What was once solely within the purview of the neurosurgeon grew to include plastic surgeons as well as many other multi-disciplinary contributors to ensure the best patient care. In modern practice at most large academic institutions, these operations are taken on as full cranial vault reconstructions with multiple teams. This entails not only removing the pathologic segment of skull as done historically but also more closely modeling the skull to normal physiology to allow for appropriate growth of the skull and brain without risk of increasing ICP and finally to achieve cosmesis.

Management of Lambdoid

Craniosynostosis
An important consideration in undertaking this operation is the optimal time point for surgery. This is a debated topic within the field, as the balance of risks and benefits changes with time. Intervening when the patient is younger (e.g., 2-6 months) provides a simpler operation because the bone is softer and more malleable and can be more easily removed. Endoscopic suturectomy can be used during these cases [111]. However, younger age confers a larger anesthetic risk with the potential for lasting effects, and the treatment benefits may not be as durable for endoscopic procedures, even requiring helmet orthoses for significant periods postoperatively to maintain positioning. Waiting for the patient to mature further (6-12 months) allows for a more definitive correction of the deformity and more directly achieved cosmesis via contouring [112]. However, the bone has become further mineralized and is more difficult to manipulate while also causing more bleeding and a greater rate of side effects.

Lambdoid synostosis provides its own unique challenges in surgical management due to its rarity and intimate anatomic relationship with many crucial neurovascular structures. A thorough physical exam is critical, as lambdoid synostosis can be easily mistaken for positional plagiocephaly, and vice versa. As their treatments are opposite, consisting of operative correction for lambdoid craniosynostosis or positional changes or orthoses for positional plagiocephaly, the diagnosis should be verified prior to any attempted surgical intervention. Physical exam findings can distinguish the 2 conditions. While both have occipital flattening, the position of the mastoid and the ear is closely observed. In true lambdoid synostosis, the ipsilateral mastoid is elongated, and the ipsilateral ear is inferiorly displaced. Contralateral bossing of the frontal and parietal bones can be observed as well, secondary to brain expansion opposite the fused suture. Positional plagiocephaly does not typically present with these findings [113]. Additionally, the skull base itself is slightly tilted, resulting in a trapezoid shape in the head when viewed from above. Positional plagiocephaly involves a parallelogram shape when viewed from the same vantage point. CT scan of the head is a valuable tool to confirm a suspected diagnosis and it is highly specific for true synostosis. Side effects of ionizing radiation (tumorigenesis, developmental delay) in this age-group should always be considered prior to obtaining imaging. As part of the preoperative planning, obtaining an MRI of the head can be useful. Lambdoid synostosis can result in deformities to the posterior fossa. An increased proportion of these patients may concomitantly carry a Chiari malformation, especially if the synostosis is bilateral [114].

Pediatr Neurosurg 2022;57:1-16

DOI: $10.1159 / 000519175$ 


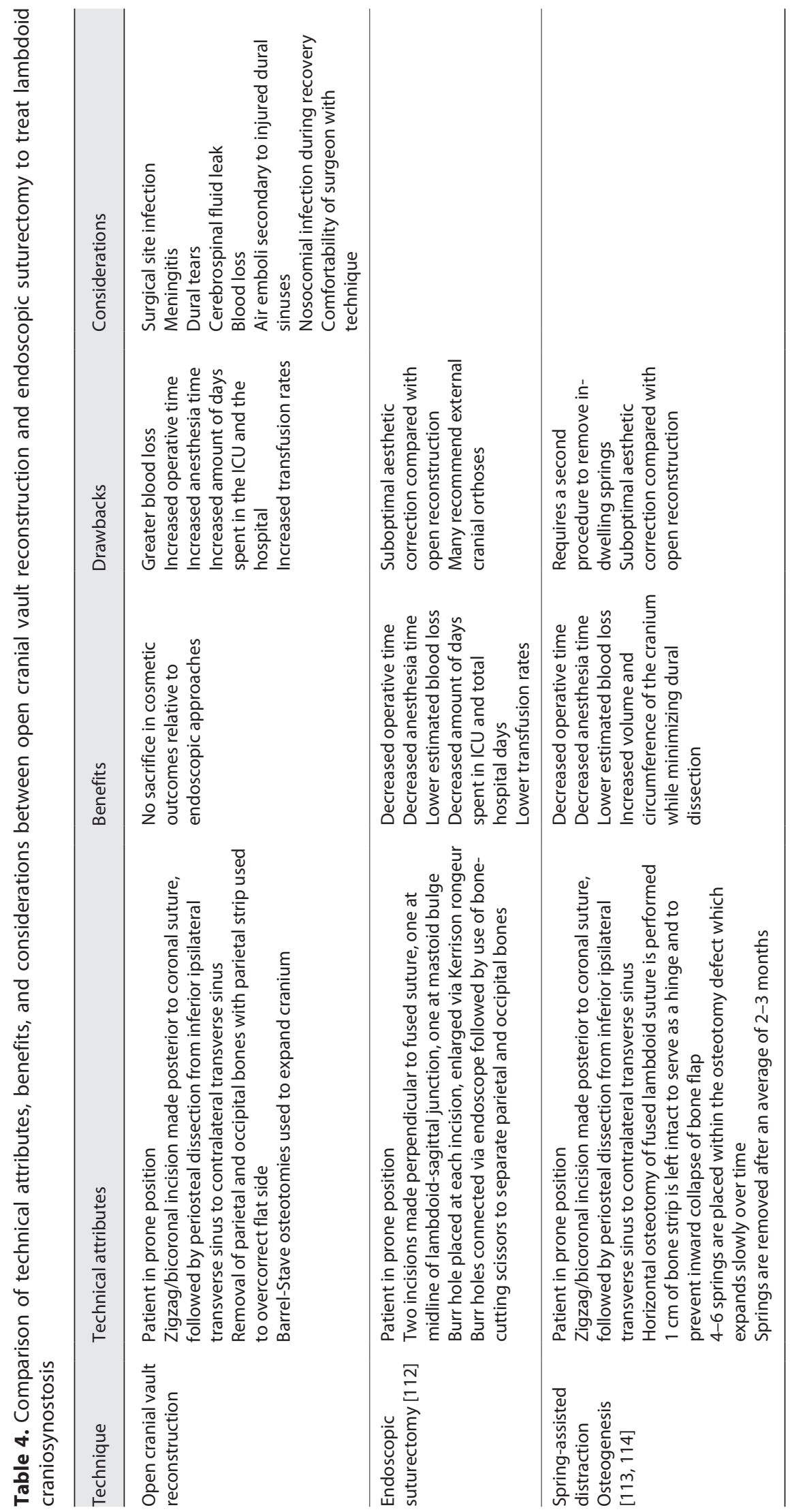


An MRI allows identification of this preoperatively, allowing for modification of the treatment approach or management of resultant hydrocephalus. MRI also localizes important vascular structures such as the torcula and the transverse venous sinuses and their relation to the suture.

The 3 main surgical approaches are open cranial vault reconstruction, endoscopic suturectomy, and spring-assisted distraction osteogenesis [112-115]. A comparison of these techniques, along with their technical attributes, benefits, and considerations, is summarized in Table 4. In open reconstruction, the patient is positioned prone, and a coronal zigzag or bicoronal incision is made slightly posterior to the coronal suture. Periosteal dissection is then carried out inferiorly below the level of the transverse sinus ipsilaterally and posteriorly to the level of the transverse sinus on the contralateral side. The parietal and occipital bones are then removed bilaterally; this can be done en-bloc or keeping a central strip of bone in place. Dura must be meticulously dissected from the bone prior to this step, as the venous sinuses may be embedded within the bone. A strip of parietal skull from the craniectomy is taken, often from the vertex of the skull in the coronal plane, and rotated inferiorly $180^{\circ}$ to be placed at the inferior aspect of the craniectomy to ensure overcorrection of the flat side. The bones removed are contoured ex vivo and replaced, and fragments are connected and distracted using absorbable plates with screws and/or wires. The correction of the flat side may also be achieved by separating the occipital bones and switching the right and left sides in cranioplasty to provide increased volume to the affected side. Barrel-stave osteotomies are also made to expand the cranium [115]. In endoscopic treatment, a patient is also positioned prone, and 2 incisions are made perpendicular to the fused suture: one near the junction of the lambdoid and sagittal suture at the midline and one over the mastoid bulge. A burr hole is placed at each location over the suture and enlarged with a Kerrison rongeur. The holes are then connected via the endoscope, and after dura is freely dissected from bone, bone-cutting scissors are used to completely free the parietal bone from the occipital bone [114].

Spring-assisted distraction osteogenesis has been shown to increase the AP length of the skull and total skull circumference [113]. An osteotomy is performed with a $1-\mathrm{cm}$ remnant bone strip left to prevent inward collapse. The bone flap remains attached to the lambdoid suture. Depending on age, 4-6 springs can be placed within the osteotomy defect and can expand over time, with springs being left in for an average of 76 days [113].
Surgical Outcomes and Postoperative Considerations

While the treatment of craniosynostosis has become safer over time, there are many important intraoperative and postoperative considerations. These depend on the type of operation, namely open cranial vault reconstruction versus endoscopic correction. In a retrospective series of 19 patients surgically treated with isolated lambdoid synostosis, endoscopic correction has a significantly lower rate of operative time, anesthesia time, estimated blood loss, intensive care unit days, and hospital days when compared with open correction [114]. Additionally, surgical site infection, meningitis, dural tear, cerebrospinal fluid leak, and, perhaps most importantly, blood loss are acute complications that should be assessed for. Due to the smaller circulating blood volume in infants and the high degree of bony bleeding for open reconstruction, many surgical groups have instituted protocols to decrease blood loss and transfusion rate, such as preoperative erythropoietin administration or intraoperative blood cycling $[109,116]$. These complications can ultimately lead to severe anemia and end-organ injury. Lastly, a rare but devastating complication is migration of an air embolus through an injured dural sinus, leading to massive cerebral infarct, given that the lambdoid suture is anatomically intimate with the transverse sinus, torcula, and the sagittal sinus. This can be monitored for intraoperatively with precordial doppler ultrasound [92].

Initially, many centers keep the patient in the intensive care unit for closer monitoring of lab values and to ensure that critical anemia does not develop, though there is some debate whether routine ICU admission is required [117]. If the endoscopic procedure is performed, the child often wears a helmet-molding orthosis for 4-6 months after postoperative swelling has resolved to ensure the absence of refusion and shift the free bone flaps into an appropriate position as the brain expands. Late complicationsincludecontourirregularities, failureofreossification, and refusion of suture, all of which may require reoperation. Many studies have shown that endoscopic correction can achieve comparable outcomes to cranial vault reconstruction in lambdoid synostosis $[114,118]$. It is important to continue to follow these patients longitudinally, as these complications can present years after surgery.

\section{Conclusion}

Lambdoid craniosynostosis is a rare variant of craniosynostosis that can lead to developmental delay, facial abnormality, and neurological dysfunction. Surgical correc- 
tion with postoperative helmet orthosis is the preferred method of treatment, with encouraging long-term results. Clinicians must be able to recognize isolated lambdoid craniosynostosis based upon clinical and imaging characteristics and provide timely surgical management to avoid cosmetic and neurological deficits.

\section{Conflict of Interest Statement}

The authors have no conflicts of interest to declare.

\section{Author Contributions}

Taylor Reardon suggested and developed the idea and contributed to the Abstract, Introduction, and Radiologic Presentation sections. Dr. Brian Fiani provided mentorship and document editing and contributed to the Conclusion section. Dr. Jacob Kosarchuk provided mentorship and contributed to the Demographics, Embryological Development, Pathogenesis, and Clinical Presentation and Neurological Sequelae sections. Dr. Anthony Parisi provided mentorship and contributed to the Surgical Techniques and Surgical Outcomes and Postoperative Considerations sections. Nathan A. Shlobin conducted the systematic review and contributed to the Methods and Results sections. All the authors fulfilled the ICMJE Criteria for Authorship.

\section{Funding Sources}

The authors received no specific funding for this work.

\section{References}

1 Gracia A, Martínez-Lage JF, Arsuaga JL, Martínez I, Lorenzo C, Pérez-Espejo MA. The earliest evidence of true lambdoid craniosynostosis: the case of "Benjamina", a homo heidelbergensis child. Childs Nerv Syst. 2010 Apr; 26(6):723-7.

2 Smartt JMJr, Reid RR, Singh DJ, Bartlett SP. True lambdoid craniosynostosis: long-term results of surgical and conservative therapy. Plast Reconstr Surg. 2007 Sep 15;120(4):993-1003.

3 Kadlub N, Persing JA, da Silva Freitas R, Shin $\mathrm{JH}$. Familial lambdoid craniosynostosis between father and son. J Craniofac Surg. 2008 May;19(3):850-4.

4 Rogers GF, Edwards PD, Robson CD, Mulliken JB. Concordant contralateral lambdoidal synostosis in dizygotic twins. J Craniofac Surg. 2005 May;16(3):435-9.

5 Borad V, Cordes EJ, Liljeberg KM, Sylvanus TS, Lim PK, Wood RJ. Isolated lambdoid craniosynostosis. J Craniofac Surg. 2019 NovDec;30(8):2390-2.

6 Page MJ, Moher D, Bossuyt PM, Boutron I, Hoffmann TC, Mulrow CD, et al. PRISMA 2020 explanation and elaboration: updated guidance and exemplars for reporting systematic reviews. BMJ. 2021;372:n160.

7 The World Bank. World Bank Country and Lending Groups. The World Bank Group. Available from: https://datahelpdesk.worldbank.org/knowledgebase/articles/906519world-bank-country-and-lending-groups.

8 Guyatt GH, Oxman AD, Vist GE, Kunz R, Falck-Ytter Y, Alonso-Coello P, et al. GRADE: an emerging consensus on rating quality of evidence and strength of recommendations. BMJ. 2008;336(7650):924-6.

9 Sterne JA, Hernán MA, Reeves BC, Savović J, Berkman ND, Viswanathan M, et al. ROBINS-I: a tool for assessing risk of bias in nonrandomised studies of interventions. BMJ. 2016;355:i4919.
10 Abu-Ghname A, Masoumy M, Basagaoglu B, Dempsey RF, Dauser RC, Maricevich RS. A novel Sand Dollar and Staves technique for unilateral lambdoid craniosynostosis. J Craniofac Surg. 2021 Jan-Feb 01;32(1):27-31.

11 Jimenez DF, Barone CM. Endoscopic craniectomy for early surgical correction of sagittal craniosynostosis. J Neurosurg. 1998 Jan; 88(1):77-81.

12 Baumgartner JE, Teichgraeber JF, Waller AL, Grantcherova E, Gateno J, Xia JJ. Microscopic approach to craniosynostosis. J Craniofac Surg. 2005 Nov; 16(6):997-1005.

13 Cartwright CC, Jimenez DF, Barone CM, Baker L. Endoscopic strip craniectomy: a minimally invasive treatment for early correction of craniosynostosis. J Neurosci Nurs. 2003 Jun;35(3):130-8.

14 Collett BR, Kapp-Simon KA, Wallace E, Cradock MM, Buono L, Speltz ML. Attention and executive function in children with and without single-suture craniosynostosis. Child Neuropsychol. 2017 Jan;23(1):83-98.

15 Dias MS, Klein DM, Backstrom JW. Occipital plagiocephaly: deformation or lambdoid synostosis? I. Morphometric analysis and results of unilateral lambdoid craniectomy. Pediatr Neurosurg. 1996;24(2):61-8.

16 Elliott RM, Smartt JMJr, Taylor JA, Bartlett SP. Does conventional posterior vault remodeling alter endocranial morphology in patients with true lambdoid synostosis? J Craniofac Surg. 2013 Jan;24(1):115-9.

17 Fearon JA, Ruotolo RA, Kolar JC. Single sutural craniosynostoses: surgical outcomes and long-term growth. Plast Reconstr Surg. 2009 Feb;123(2):635-42.

18 Fearon JA, Dimas V, Ditthakasem K. Lambdoid craniosynostosis: the relationship with Chiari deformations and an analysis of surgical outcomes. Plast Reconstr Surg. 2016 Mar; 137(3):946-51.
19 Jimenez DF, Barone CM. The sunrise technique: the correction of occipital plagiocephaly using bandeau occipital plate and radial osteotomies. Pediatr Neurosurg. 1995;22(3): 162-6; discussion 166.

20 Kaiser G. The clinical significance of bilateral synostosis of the lambdoid suture and the usefulness of its treatment. Childs Brain. 1984; 11(2):87-98.

21 Kamel GN, McKee RM, Carbulido K, Modi R, Belza C, Ewing E, et al. A posterior rotational flap technique using distraction osteogenesis for unilateral lambdoid craniosynostosis. J Craniofac Surg. 2021 Jan 7. Publish Ahead of Print.

22 Komuro Y, Yanai A, Hayashi A, Miyajima M, Nakanishi H, Arai H. Treatment of unilateral lambdoid synostosis with cranial distraction. J Craniofac Surg. 2004 Jul;15(4):609-13.

23 Mittermiller PA, Rochlin DH, Menard RM. Endoscopic spring-mediated distraction for unilambdoid craniosynostosis. J Craniofac Surg. 2020 Oct;31(7):2097-100.

24 Muakkassa KF, Hoffman HJ, Hinton DR, Hendrick EB, Humphreys RP, Ash J. Lambdoid synostosis. Part 2: review of cases managed at The Hospital for Sick Children, 19721982. J Neurosurg. 1984 Aug;61(2):340-7.

25 Park DH, Yoon SH. The trans-sutural distraction osteogenesis for 22 cases of craniosynostosis: a new, easy, safe, and efficient method in craniosynostosis surgery. Pediatr Neurosurg. 2011;47(3):167-75.

26 Park DH, Yoon SH. Transsutural distraction osteogenesis for 285 children with craniosynostosis: a single-institution experience. J Neurosurg Pediatr. 2016 Feb;17(2):230-9.

27 Persing JA, Delashaw JB, Jane JA, Edgerton MT. Lambdoid synostosis: surgical considerations. Plast Reconstr Surg. 1988 Jun;81(6): 852-60. 
28 Pople IK, Sanford RA, Muhlbauer MS. Clinical presentation and management of 100 infants with occipital plagiocephaly. Pediatr Neurosurg. 1996 Jul;25(1):1-6.

29 Rattani A, Riordan CP, Meara JG, Proctor MR. Comparative analysis of cranial vault remodeling versus endoscopic suturectomy in the treatment of unilateral lambdoid craniosynostosis. J Neurosurg Pediatr. 2020 Apr 17: $1-8$.

30 Rodriguez-Feo C, Winocour J, Ramirez R, Spear M, Kelly K. Twenty-year review of a single surgeon's experience using a unique surgical technique to correct lambdoidal lynostosis. J Craniofac Surg. 2017 Oct;28(7):1761-5.

31 Salehi A, Ott K, Skolnick GB, Nguyen DC, Naidoo SD, Kane AA, et al. Neosuture formation after endoscope-assisted craniosynostosis repair. J Neurosurg Pediatr. 2016 Aug; 18(2):196-200.

32 Satoh K, Mitsukawa N. Suitable indication for the application of distraction osteogenesis: occipital enlargement for lambdoid synostosis. J Craniofac Surg. 2013 Sep;24(5):1530-4.

33 Scott WW, Fearon JA, Swift DM, Sacco DJ. Suboccipital decompression during posterior cranial vault remodeling for selected cases of chiari malformations associated with craniosynostosis. J Neurosurg Pediatr. 2013 Aug; 12(2):166-70.

34 Sgouros S, Goldin JH, Hockley AD, Wake MJ Posterior skull surgery in craniosynostosis. Childs Nerv Syst. 1996 Nov;12(11):727-33.

35 Sloan GM, Wells KC, Raffel C, McComb JG. Surgical treatment of craniosynostosis: outcome analysis of 250 consecutive patients. Pediatrics. 1997 Jul;100(1):E2.

36 Smartt JMJr, Reid RR, Singh DJ, Bartlett SP. True lambdoid craniosynostosis: long-term results of surgical and conservative therapy. Plast Reconstr Surg. 2007 Sep 15;120(4):9931003.

37 Teichgraeber JF, Baumgartner JE, Viviano SL, Gateno J, Xia JJ. Microscopic versus open approach to craniosynostosis: a long-term outcomes comparison. J Craniofac Surg. 2014 Jul;25(4):1245-8.

38 Thaller SR, Hoyt J, Boggan J. Surgical correction of unilateral lambdoid synostosis: occipital rotation flap. J Craniofac Surg. 1992 Jul; 3(1):12-9; discussion 18-9.

39 Thatikunta M, Pearson L, Nguyen C, John K, Abolfotoh M, Mutchnick I, et al. Three-dimensional volumetric changes in posterior vault distraction with distraction osteogenesis. J Craniofac Surg. 2020 Jul-Aug;31(5): 1301-6.

40 Vander Kolk CA, Carson BS, Robertson BC, Manson PN. The occipital bar and internal osteotomies in the treatment of lambdoidal synostosis. J Craniofac Surg. 1993 Apr;4(2): $112-8$.

41 Vinchon M, Guerreschi P, Karnoub MA, Wolber A. Synostosis of the lambdoid suture: a spectrum. Childs Nerv Syst. 2021 Jun;37(6): 1991-2000. Epub 2021 Jan 6.
42 Weimin S, Cui J, Chen J, Gao Q. Treatment of unilateral lambdoid synostosis using cranium distraction osteogenesis with Z-shaped osteotomy. Ann Plast Surg. 2017 Mar;78(3):2948

43 Wilbrand JF, Szczukowski A, Blecher JC Pons-Kuehnemann J, Christophis P, Howaldt $\mathrm{HP}$, et al. Objectification of cranial vault correction for craniosynostosis by three-dimensional photography. J Craniomaxillofac Surg. 2012 Dec;40(8):726-30.

44 Wilbrand JF, Howaldt HP, Reinges M, Christophis P. Surgical correction of lambdoid synostosis: new technique and first results. J Craniomaxillofac Surg. 2016 Oct;44(10):1531-5.

45 Zöller JE, Mischkowski RA, Speder B. Preliminary results of standardized occipital advancement in the treatment of lambdoid synostosis. J Craniomaxillofac Surg. 2002 Dec; 30(6):343-8.

46 Zubovic E, Woo AS, Skolnick GB, Naidoo SD, Smyth MD, Patel KB. Cranial base and posterior cranial vault asymmetry after open and endoscopic repair of isolated lambdoid craniosynostosis. J Craniofac Surg. 2015 Jul; 26(5):1568-73.

47 Di Rocco F, Arnaud E, Renier D. Evolution in the frequency of nonsyndromic craniosynostosis. J Neurosurg Pediatr. 2009 Jul;4(1):21-5.

48 Boulet SL, Rasmussen SA, Honein MA. A population-based study of craniosynostosis in metropolitan Atlanta, 1989-2003. Am J Med Genet A. 2008 Apr 15;146A(8):984-91.

49 Lajeunie E, Le Merrer M, Bonaïti-Pellie C, Marchac D, Renier D. Genetic study of nonsyndromic coronal craniosynostosis. Am J Med Genet. 1995 Feb 13;55(4):500-4.

50 Persing JA. MOC-PS(SM) CME article: management considerations in the treatment of craniosynostosis. Plast Reconstr Surg. 2008 Apr;121(4 Suppl 1):1-11.

51 Lajeunie E, Crimmins DW, Arnaud E, Renier D. Genetic considerations in nonsyndromic midline craniosynostoses: a study of twins and their families. J Neurosurg. 2005;4103: 353-6.

52 Kjaer I. Neuro-osteology. Crit Rev Oral Biol Med. 1998;9(2):224-44.

53 Kimonis V, Gold JA, Hoffman TL, Panchal J, Boyadjiev SA. Genetics of craniosynostosis. Semin Pediatr Neurol. 2007 Sep;14(3):15061.

54 Greenwood J, Flodman P, Osann K, Boyadjiev SA, Kimonis V. Familial incidence and associated symptoms in a population of individuals with nonsyndromic craniosynostosis. Genet Med. 2014 Apr;16(4):302-10.

55 Nah HD, Pacifici M, Gerstenfeld LC, Adams SL, Kirsch T. Transient chondrogenic phase in the intramembranous pathway during normal skeletal development. J Bone Miner Res. 2010;15(3):522-33.

56 Chai Y, Maxson REJr. Recent advances in craniofacial morphogenesis. Dev Dyn. 2006 Sep; 235(9):2353-75.
57 Cohen MMJr. Sutural biology and the correlates of craniosynostosis. Am J Med Genet. 1993 Oct 1;47(5):581-616.

58 Slater BJ, Lenton KA, Kwan MD, Gupta DM, Wan DC, Longaker MT. Cranial sutures: a brief review. Plast Reconstr Surg. 2008 Apr; 121(4):170e-8e.

59 Gong SG. Cranial neural crest: migratory cell behavior and regulatory networks. Exp Cell Res. 2014 Jul 15;325(2):90-5.

60 Kouskoura T, Fragou N, Alexiou M, John N, Sommer L, Graf D, et al. The genetic basis of craniofacial and dental abnormalities. Schweiz Monatsschr Zahnmed. 2011;121:636-46.

61 Twigg SR, Wilkie AO. A genetic-pathophysiological framework for craniosynostosis. Am J Hum Genet. 2015 Sep 3;97(3):359-77.

62 Zhao X, Qu Z, Tickner J, Xu J, Dai K, Zhang $X$. The role of SATB2 in skeletogenesis and human disease. Cytokine Growth Factor Rev. $2014 \mathrm{Feb} ; 25(1): 35-44$.

63 Morriss-Kay GM, Wilkie AO. Growth of the normal skull vault and its alteration in craniosynostosis: insights from human genetics and experimental studies. J Anat. 2005 Nov; 207(5):637-53.

64 Katsianou MA, Adamopoulos C, Vastardis H, Basdra EK. Signaling mechanisms implicated in cranial sutures pathophysiology: craniosynostosis. BBA Clin. 2016 Apr 29;6:165-76.

65 Ogle RC, Tholpady SS, McGlynn KA, Ogle RA. Regulation of cranial suture morphogenesis. Cells Tissues Organs. 2004;176(1-3):5466.

66 Chim H, Manjila S, Cohen AR, Gosain AK. Molecular signaling in pathogenesis of craniosynostosis: the role of fibroblast growth factor and transforming growth factor- $\beta$. Neurosurg Focus. 2011 Aug;31(2):E7.

67 Opperman LA. Cranial sutures as intramembranous bone growth sites. Dev Dyn. 2000 Dec;219(4):472-85.

68 Delashaw JB, Persing JA, Jane JA. Cranial deformation in craniosynostosis. A new explanation. Neurosurg Clin N Am. 1991 Jul;2(3): 611-20.

69 Wilkie AO, Byren JC, Hurst JA, Jayamohan J, Johnson D, Knight SJ, et al. Prevalence and complications of single-gene and chromosomal disorders in craniosynostosis. Pediatrics. 2010 Aug; 126(2):e391-400.

70 Meyers GA, Day D, Goldberg R, Daentl DL, Przylepa KA, Abrams LJ, et al. FGFR2 exon IIIa and IIIc mutations in Crouzon, JacksonWeiss, and Pfeiffer syndromes: evidence for missense changes, insertions, and a deletion due to alternative RNA splicing. Am J Hum Genet. 1996 Mar;58(3):491-8.

71 Rutland P, Pulleyn LJ, Reardon W, Baraitser M, Hayward R, Jones B, et al. Identical mutations in the FGFR2 gene cause both Pfeiffer and Crouzon syndrome phenotypes. Nat Genet. 1995 Feb;9(2):173-6.

72 Marie PJ, Kaabeche K, Guenou H. Roles of FGFR2 and twist in human craniosynostosis: insights from genetic mutations in cranial osteoblasts. Front Oral Biol. 2008;12:144-59. 
73 Azoury SC, Reddy S, Shukla V, Deng CX. Fibroblast Growth Factor Receptor 2 (FGFR2) mutation related syndromic craniosynostosis. Int J Biol Sci. 2017 Nov 2;13(12):1479-88.

74 Kirschner RE, Gannon FH, Xu J, Wang J, Karmacharya J, Bartlett SP, et al. Craniosynostosis and altered patterns of fetal TGF-beta expression induced by intrauterine constraint. Plast Reconstr Surg. 2002 Jun;109(7):233854; discussion 2347-54.

75 Chong SL, Mitchell R, Moursi AM, Winnard P, Losken HW, Bradley J, et al. Rescue of coronal suture fusion using transforming growth factor-beta 3 (Tgf-beta 3 ) in rabbits with delayedonset craniosynostosis. Anat Rec A Discov Mol Cell Evol Biol. 2003 Oct;274(2):962-71.

76 Kosty J, Vogel TW. Insights into the development of molecular therapies for craniosynostosis. Neurosurg Focus. 2015 May;38(5):E2.

77 Ciurea AV, Toader C. Genetics of craniosynostosis: review of the literature. J Med Life. 2009 Jan-Mar;2(1):5-17.

78 Sharma VP, Fenwick AL, Brockop MS, McGowan SJ, Goos JA, Hoogeboom AJ, et al. Mutations in TCF12, encoding a basic helixloop-helix partner of TWIST1, are a frequent cause of coronal craniosynostosis. Nat Genet. 2013 Mar;45(3):304-7.

79 Jabs EW. Toward understanding the pathogenesis of craniosynostosis through clinical and molecular correlates. Clin Genet. 1998 Feb;53(2):79-86.

80 Wilkie AO, Tang Z, Elanko N, Walsh S, Twigg SR, Hurst JA, et al. Functional haploinsufficiency of the human homeobox gene MSX2 causes defects in skull ossification. Nat Genet. 2000 Apr;24(4):387-90.

81 Governale LS. Craniosynostosis. Pediatr Neurol. 2015 Nov;53(5):394-401.

82 Gedzelman E, Meador KJ. Antiepileptic drugs in women with epilepsy during pregnancy. Ther Adv Drug Saf. 2012 Apr;3(2):71-87.

83 Lajeunie E, Barcik U, Thorne JA, El Ghouzzi V, Bourgeois M, Renier D. Craniosynostosis and fetal exposure to sodium valproate. J Neurosurg. 2001 Nov;95(5):778-82.

84 Sanchez-Lara PA, Carmichael SL, Graham JMJr, Lammer EJ, Shaw GM, Ma C, et al. National Birth Defects Prevention Study. Fetal constraint as a potential risk factor for craniosynostosis. Am J Med Genet A. 2010 Feb; $152 \mathrm{~A}(2): 394-400$

85 Carmichael SL, Ma C, Rasmussen SA, Honein MA, Lammer EJ, Shaw GM. National Birth Defects Prevention Study. Craniosynostosis and maternal smoking. Birth Defects Res A Clin Mol Teratol. 2008 Feb;82(2):78-85.

86 Heuzé Y, Holmes G, Peter I, Richtsmeier JT, Jabs EW. Closing the gap: genetic and genomic continuum from syndromic to nonsyndromic craniosynostoses. Curr Genet Med Rep. 2014 Sep 1;2(3):135-45.

87 Kutkowska-Kaźmierczak A, Gos M, Obersztyn E. Craniosynostosis as a clinical and diagnostic problem: molecular pathology and genetic counseling. J Appl Genet. 2018 May; 59(2):133-47.
88 Johnson D, Wilkie AO. Craniosynostosis. Eur J Hum Genet. 2011;19:369-76.

89 Lajeunie E, Cameron R, El Ghouzzi V, de Parseval N, Journeau P, Gonzales M, et al. Clinical variability in patients with Apert's syndrome. J Neurosurg. 1999 Mar;90(3): 443-7.

90 Delashaw JB, Persing JA, Broaddus WC, Jane JA. Cranial vault growth in craniosynostosis. J Neurosurg. 1989 Feb;70(2):15965 .

91 Kajdic N, Spazzapan P, Velnar T. Craniosynostosis: recognition, clinical characteristics, and treatment. Bosn J Basic Med Sci. 2018 May 20;18(2):110-6.

92 Dempsey RF, Monson LA, Maricevich RS, Truong TA, Olarunnipa S, Lam SK, et al. Nonsyndromic craniosynostosis. Clin Plast Surg. 2019 Apr;46(2):123-39.

93 Johns FR, Jane JA, Lin KY. Surgical approach to posterior skull deformity. Neurosurg Focus. 2000;9(3):E4.

94 Jimenez DF, Barone CM, Argamaso RV, Goodrich JT, Shprintzen RJ. Asterion region synostosis. Cleft Palate Craniofac J. 1994; 31(2):136-41.

95 Mawji A, Vollman AR, Hatfield J, McNeil DA, Sauvé R. The incidence of positional plagiocephaly: a Cohort Study. Pediatrics. 2013 Aug;132(2):298-304.

96 Sharma RK. Craniosynostosis. Indian J Plast Surg. 2013 Jan;46(1):18-27.

97 Haas-Lude K, Wolff M, Will B, Bender B, Krimmel M. Clinical and imaging findings in children with non-syndromic lambdoid synostosis. Eur J Pediatr. 2014;173:435-40.

98 Hassell S, Butler MG. Antley-Bixler syndrome: report of a patient and review of literature. Clin Genet. 1994 Nov;46(5):372-6.

99 Sawh-Martinez R, Steinbacher DM. Syndromic craniosynostosis. Clin Plast Surg. 2019 Apr;46(2):141-55.

100 Speltz ML, Collett BR, Wallace ER, Starr JR, Cradock MM, Buono L, et al. Intellectual and academic functioning of school-age children with single-suture craniosynostosis. Pediatrics. 2015 Mar;135(3):e615-23.

101 Starr JR, Collett BR, Gaither R, Kapp-Simon KA, Cradock MM, Cunningham ML, et al. Multicenter Study of neurodevelopment in 3 -year-old children with and without singlesuture craniosynostosis. Arch Pediatr Adolesc Med. 2012;166(6):536-42.

102 Thompson DN, Harkness W, Jones B, Gonsalez S, Andar U, Hayward R. Subdural intracranial pressure monitoring in craniosynostosis: its role in surgical management. Childs Nerv Syst. 1995 May;11(5):269-75.

103 Thompson DN, Malcolm GP, Jones BM, Harkness WJ, Hayward RD. Intracranial pressure in single-suture craniosynostosis. Pediatr Neurosurg. 1995;22(5):235-40.

104 Motch Perrine SM, Stecko T, Neuberger T, Jabs EW, Ryan TM, Richtsmeier JT. Integration of brain and skull in prenatal mouse models of Apert and Crouzon syndromes. Front Hum Neurosci. 2017 Jul;11(11):369.
105 Kapp-Simon KA, Speltz ML, Cunningham ML, Patel PK, Tomita T. Neurodevelopment of children with single suture craniosynostosis: a review. Childs Nerv Syst. 2007 Mar; 23(3):269-81.

106 Massimi L, Bianchi F, Frassanito P, Calandrelli R, Tamburrini G, Caldarelli M. Imaging in craniosynostosis: when and what? Childs Nerv Syst. 2019 Nov;35(11):2055-69.

107 Vander Kolk CA, Carson BS. Lambdoid synostosis. Clin Plast Surg. 1994 Oct;21(4):57584.

108 Badve CA, K MM, Iyer RS, Ishak GE, Khanna PC. Craniosynostosis: imaging review and primer on computed tomography. Pediatr Radiol. 2013 Jun;43(6):728-7.

109 Rhodes JL, Tye GW, Fearon JA. Craniosynostosis of the lambdoid suture. Semin Plast Surg. 2014 Aug;28(3):138-43.

110 Cinalli G, Spennato P, Sainte-Rose C, Arnaud E, Aliberti F, Brunelle F, et al. Chiari malformation in craniosynostosis. Childs Nerv Syst. 2005;21:889-901.

111 Proctor MR, Meara JG. A review of the management of single-suture craniosynostosis, past, present, and future. J Neurosurg Pediatr. 2019;24(6):622-31.

112 Bozkurt S, Borghi A, van de Lande LS, Jeelani NUO, Dunaway DJ, Schievano S. Computational modelling of patient specific spring assisted lambdoid craniosynostosis correction. Sci Rep. 2020 Oct 29;10(1): 18693.

113 de Jong T, van Veelen ML, Mathijssen IM Spring-assisted posterior vault expansion in multisuture craniosynostosis. Childs Nerv Syst. 2013 May;29(5):815-20.

114 Rattani A, Riordan CP, Meara JG, Proctor MR. Comparative analysis of cranial vault remodeling versus endoscopic suturectomy in the treatment of unilateral lambdoid craniosynostosis. J Neurosurg Pediatr. 2020 Apr 17:1-8.

115 Zubovic E, Woo AS, Skolnick GB, Naidoo SD, Smyth MD, Patel KB. Cranial base and posterior cranial vault asymmetry after open and endoscopic repair of isolated lambdoid craniosynostosis. J Craniofac Surg. 2015 Jul; 26(5):1568-73.

116 Fearon JA, Weinthal J. The use of recombinant erythropoietin in the reduction of blood transfusion rates in craniosynostosis repair in infants and children. Plast Reconstr Surg. 2002 Jun;109(7):2190-6.

117 Bonfield CM, Basem J, Cochrane DD, Singhal A, Steinbok P. Examining the need for routine intensive care admission after surgical repair of nonsyndromic craniosynostosis: a preliminary analysis. J Neurosurg Pediatr. 2018 Dec 1;22(6):616-9.

118 Zubovic E, Woo AS, Skolnick GB, Naidoo SD, Smyth MD, Patel KB. Cranial base and posterior cranial vault asymmetry after open and endoscopic repair of isolated lambdoid craniosynostosis. J Craniofac Surg. 2015 Jul; 26(5):1568-73. 